\title{
A Cemetery and Quarry from Imperial Gabii
}

Since 2009, the Gabii Project, an international archaeological initiative led by Nicola Terrenato and the University of Michigan, has been investigating the ancient Latin town of Gabii, which was both a neighbor of, and a rival to, Rome in the first millennium BC. The story of Gabii, like that of many ancient cities, is one of growth, transformation, and diminishment. In this volume, editors Laura M. Banducci and Anna Gallone highlight the close but sometimes tense relationship between where people live, work, trade, and bury their dead. We learn that, contrary to what you may have read elsewhere about the Roman world, the distinction between spaces of the living and spaces of the dead was not so clear-cut. Areas considered to be "within the city," or what "being in the city" implied shifted in the minds of the locals as their priorities and needs changed.

Assembled in an innovative digital format, the story of the site is presented three times in a "layered" structure: the first, titled "The Story," explains the narrative of the excavation area in a simple chronological way. The second layer, "More," contains the explanation of the phasing and the features of the site and their interpretation. The third layer contains the stratigraphic description and the technical reports on specialist materials. The volume is beautifully illustrated with traditional photographs and drawings, as well as an interactive 3D model based on photogrammetric models produced at the time of excavation. The $3 \mathrm{D}$ model is linked throughout the text by individual stratigraphic unit numbers and archaeological features. A series of interactive maps of the site, including GIS line-drawings and orthorectified aerial photographs, provide further spatial details.

Laura M. Banducci is Associate Professor of Greek and Roman Studies at Carleton University.

Anna Gallone is Professional Archaeologist and Associate Researcher at Kelsey Museum of Archaeology.

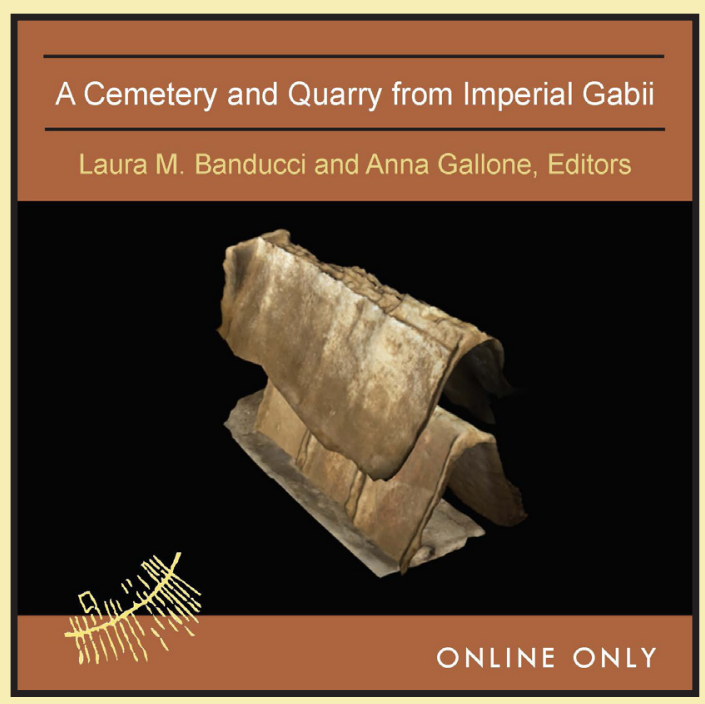

OPen ACCess 978-0-472-99906-4

Also aVailable AS AN EBOoK.

\section{UNIVERSITY OF MICHIGAN PRESS}

Order at www.press.umich.edu or 800.621.2736 